\section{Moving Toward Sustainability with Alternative Containers for Greenhouse and Nursery Crop Production: A Review and Research Update}

\author{
Susmitha Nambuthiri ${ }^{1}$, Amy Fulcher ${ }^{2,5}$, Andrew K. Koeser ${ }^{3}$, \\ Robert Geneve ${ }^{1}$, and Genhua Niu ${ }^{4}$
}

AdDitionAl INDEX wORDs. biocontainer, biodegradable container, plantable container, water use, plastic container, sustainable nursery crop production

SUMMARY. Market researchers have found that nursery and greenhouse production practices that reduce plastic use can increase consumer interest. However, there are broader crop performance, production efficiency, and environmental factors that must be considered before adopting containers made with alternative materials. This review highlights current commercially available alternative containers and parent materials. In addition, findings from recent and ongoing nursery, greenhouse, and landscape trials are synthesized, identifying common themes, inconsistencies, research gaps, and future research needs.

$\mathrm{P}$ lastic containers have been the predominant container type in U.S. greenhouse and nursery production since the 1980s. Serving a variety of functions and found in a multitude of shapes, sizes, and colors, plastic containers are used for propagating, growing, transporting, and marketing ornamental crops (Evans and Hensley, 2004; Hall et al., 2010; Helgeson et al., 2009). This reliability and flexibility come at a relatively inexpensive price, which has helped establish the prominence of plastic containers in ornamental production. Unfortunately, this combination of characteristics also creates an overabundance of unreclaimed plastic waste each production cycle. Most plastics are derived from

Mention of a trademark, proprietary product, or vendor does not constitute a guarantee or warranty of the product by the authors or their respective institutions and does not imply their approval to the exclusion of other products or vendors that may also be suitable.

The authors wish to acknowledge funding from USDA Specialty Crops Research Initiative Award 2010-51181-21212

${ }^{1}$ Department of Horticulture, N-318 Ag Sciences Center, University of Kentucky, Lexington, KY 40546

${ }^{2}$ Department of Plant Sciences, 2431 Joe Johnson Drive, Ellington Plant Science Building rm. 252, University of Tennessee, Knoxville, TN 37996

${ }^{3}$ Department of Environmental Horticulture, Center for Landscape Conservation and Ecology, IFAS, University of Florida-Gulf Coast Research and Education Center, 14625 County Road 672, Wimauma, FL 33598

${ }^{4}$ Department of Horticultural Sciences, Texas A\&M University, Texas AgriLife Research at El Paso, 1380 A\&M Circle, El Paso, TX 79927

${ }^{5}$ Corresponding author. E-mail: afulcher@utk.edu. petroleum-a nonrenewable resource that, while still relatively inexpensive, is subject to price fluctuations (Knox and Chappell, 2011). Furthermore, given limited access to recycling cencosts, and chemical contamination concerns, used plastic containers are primarily disposed of in landfills (Garthe and Kowal, 1993; Hall et al., 2010; Helgeson et al., 2009). Amidon Recycling (1994) estimated that the United States used 521 million pounds of plastic in agriculture in 1992. Of this, $66 \%$ was used in the nursery industry in the form of containers. The most recent estimate of plastic use for ornamental plant containers raises this to 1.66 billion pounds (Schrader, 2013).

Many consumers view the use of plastic products in ornamental plant production as an unsustainable practice (Behe et al., 2013). In market studies where various sustainable greenhouse plant attributes were tested, container type was consistently listed as having the greatest ters, high collection and sanitation impact on consumer product perception (Yue et al., 2011). These findings, coupled with more general market studies on green consumer habits have motivated some growers to explore avenues for making their businesses more "green"-both in terms of environmental impact and public perception (Dennis et al., 2010; Hall et al., 2009). Green industry stakeholders (i.e., nursery, greenhouse, and landscape professionals) have identified the use of plantable or compostable biodegradable container alternatives as a marketable way to improve the sustainability of current production systems. This article provides an update on advancements in the development of alternative biocontainers in nursery and greenhouse production, with the hope of fostering future research and adoption by the green industry.

\section{Types of alternative containers}

Alternative containers were developed to replace traditional petroleumbased plastic containers in nursery and greenhouse production. Plasticbased containers consume landfill space and can remain in our environment indefinitely. Sustainable containers are designed to decompose rather than contribute to landfill waste. The ability to degrade when planted or composted is a major marketing focus that distinguishes biocontainers from their conventional plastic counterparts. As such, alternative containers are classified as plantable, compostable, or recycled plastic, based on their requirements for and ability to degrade at the end of their crop production life and parent materials (Table 1 ).

Plantable. Plantable biocontainers can be planted directly into the soil. These containers are intended to withstand watering and handling

\begin{tabular}{llll}
\hline $\begin{array}{l}\text { Units } \\
\begin{array}{l}\text { To convert U.S. to SI, } \\
\text { multiply by }\end{array}\end{array}$ & U.S. unit & SI unit & $\begin{array}{l}\text { To convert SI to U.S., } \\
\text { multiply by }\end{array}$ \\
\hline 3.7854 & gal & $\mathrm{L}$ & 0.2642 \\
2.54 & inch(es) & $\mathrm{cm}$ & 0.3937 \\
25.4 & inch $(\mathrm{es})$ & $\mathrm{mm}$ & 0.0394 \\
16.3871 & inch & $\mathrm{cm}^{3}$ & 0.0610 \\
0.4536 & $\mathrm{lb}$ & $\mathrm{kg}$ & 2.2046 \\
1.6093 & mile $(\mathrm{s})$ & $\mathrm{km}$ & 0.6214 \\
33.9057 & $\mathrm{Oz} / \mathrm{yard}^{2}$ & $\mathrm{~g} \cdot \mathrm{m}^{-2}$ & 0.0295 \\
6.8948 & $\mathrm{psi}$ & $\mathrm{kPa}$ & 0.1450 \\
$\left({ }^{\circ} \mathrm{F}-32\right) \div 1.8$ & ${ }^{\circ} \mathrm{F}$ & ${ }^{\circ} \mathrm{C}$ & $\left({ }^{\circ} \mathrm{C} \times 1.8\right)+32$
\end{tabular}




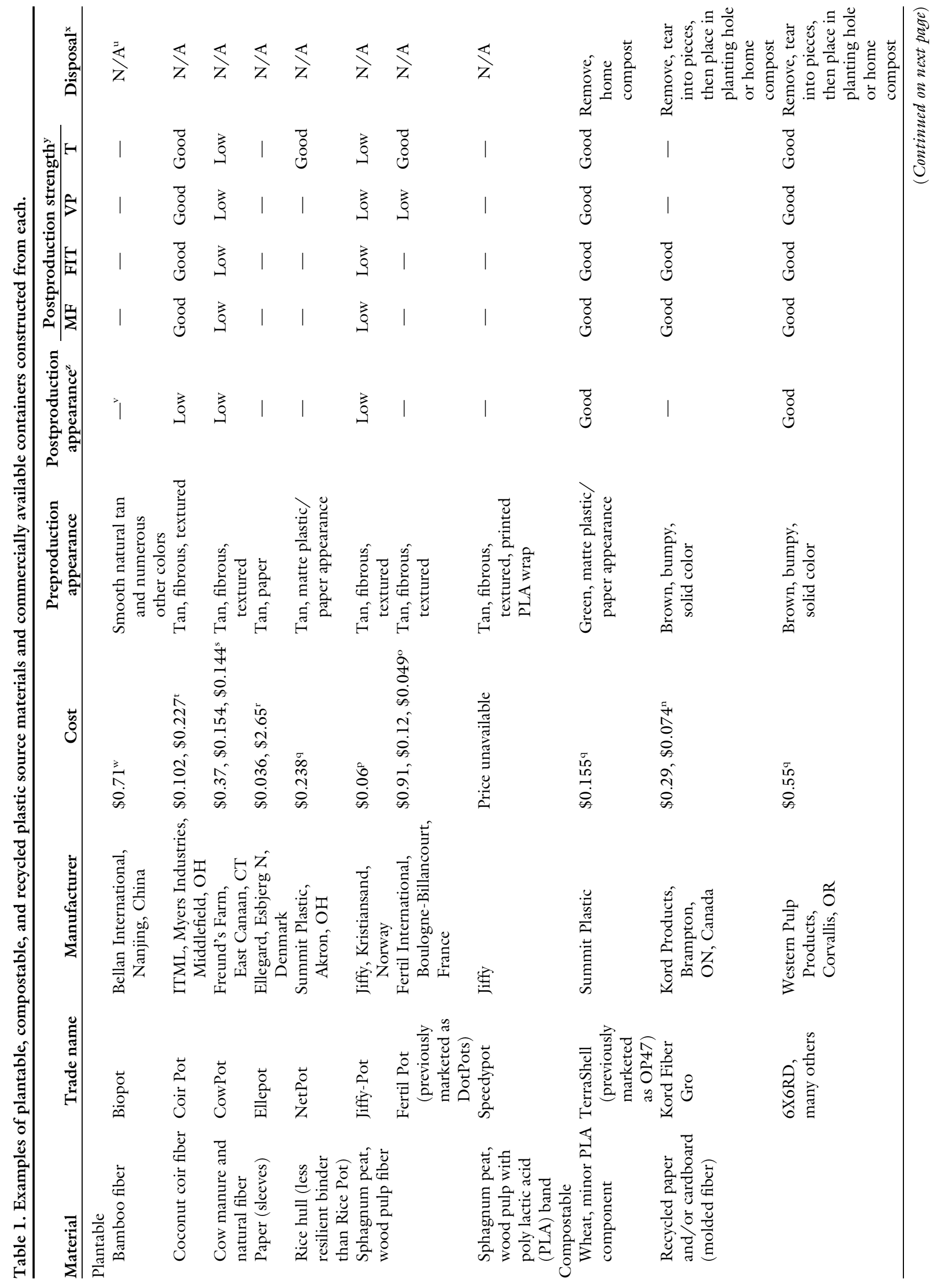

Hortlechnology · February 2015 25(1) 


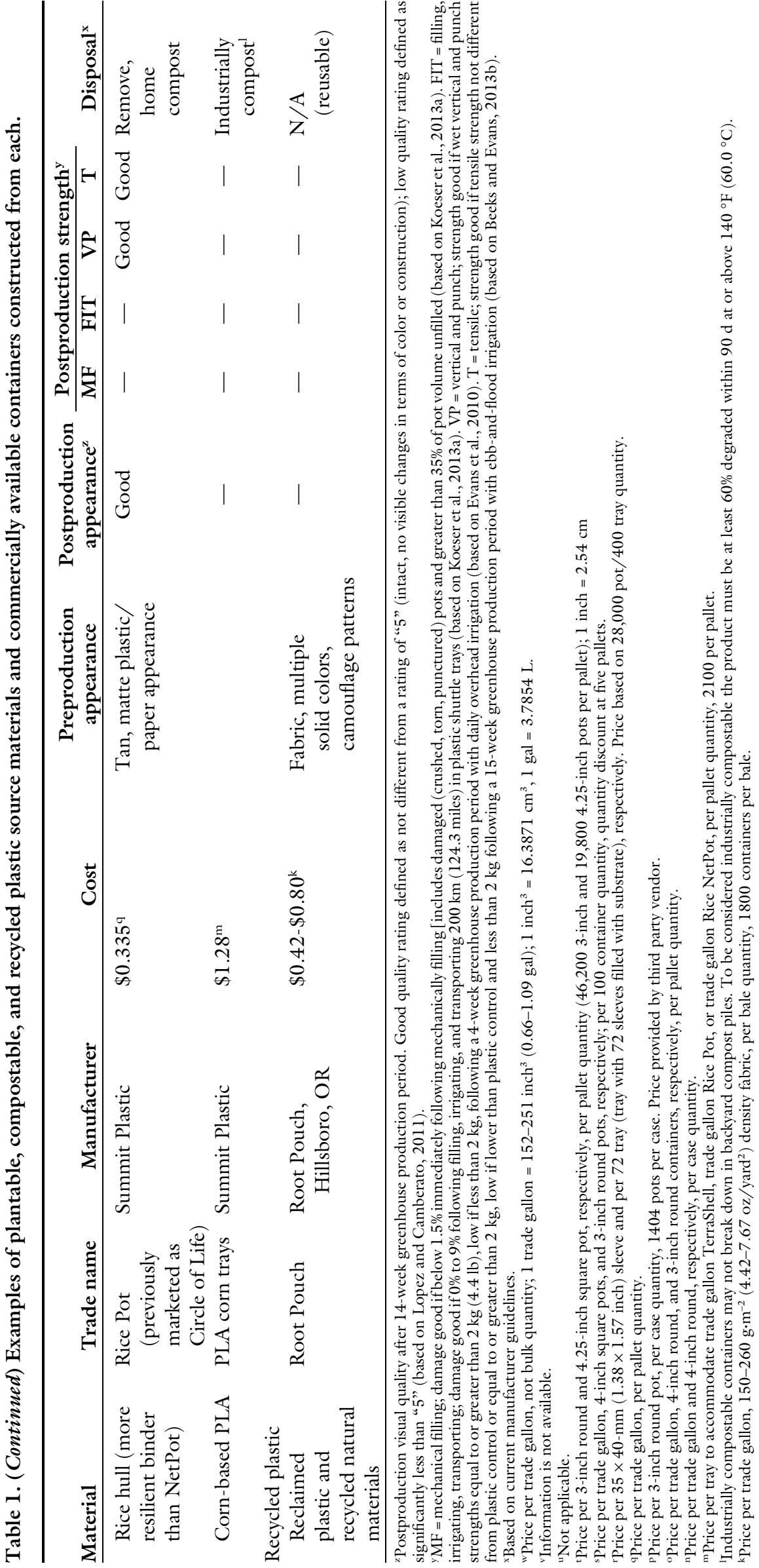

during short-term production and shipping conditions. Once planted, the containers are intended to rapidly break down and allow plant roots to penetrate the pot and grow into the soil. The use of plantable containers eliminates container removal and disposal costs and can reduce the cleanup time required at installation. Plantable containers could eliminate root disruption and transplanting shock (Khan et al., 2000). To function as claimed, it is imperative that plantable containers do in fact break down quickly once installed to allow root establishment into surrounding soil (Evans and Hensley, 2004). The rate of container biodegradation in landscapes depends on many factors. The container material, available nitrogen, moisture, temperature, $\mathrm{pH}, \mathrm{mi}^{-}$ crobes, and other soil factors can all impact degradation (unpublished data). In addition, regional differences may occur due to different soil types and climates.

Compostable. Plants must be removed from compostable containers at installation and the containers are composted separately. These containers do not degrade quickly or completely in the landscape. Most bioplastics, as well as hard rice hull, peat, and thick-walled paper or wood fiber containers intended for longer term production fall into this category. Compostable materials can be further differentiated based on whether they require industrial composting facilities to break down completely. Industrially compostable containers may not break down in a typical backyard compost pile due to unsuitable temperature, moisture, $\mathrm{pH}$, aeration, and microbial populations. ASTM D6400 is the main standard for certification of industrially compostable plastics in the United States (ASTM, 2004). According to this standard, bioplastics must be at least $60 \%$ degraded within $90 \mathrm{~d}$ at or above $140{ }^{\circ} \mathrm{F}$ to be considered compostable.

ReCyCled Plastic. These containers are produced from recycled plastic water and soft drink bottles. The used bottles are converted into a liquid and blended with biodegradable natural fibers, such as cotton, jute, vegetable fibers, or bamboo. When heat pressed, the 
mixture bonds to produce a fabric-like geotextile that is sewn into a container. These containers are not biodegradable or compostable but will slowly disintegrate to a point that leaves behind much less residue (much reduced carbon footprint) compared with plastic containers derived entirely from petrochemicals. An example of this type of product is the Root Pouch (Root Pouch, Hillsboro, OR).

\section{Materials used to produce alternative containers}

Alternative containers can be made from a variety of natural materials. These containers are generally made from renewable materials that are often by-products of an industrial process. Their use in the manufacture of containers can significantly reduce landfill waste by using waste from another process.

Pressed fiber. There are a wide variety of hot-pressed fiber containers available on the market. These are constructed from fibrous materials such as rice hulls (Oryza sativa), wheat (Triticum aestivum), paper, peat, wood pulp, spruce fibers (Picea sp.), coir fiber from coconut palm (Cocos nucifera), rice straw, bamboo (subfamily Bambusodeae), or composted cow manure. Fiber containers are semiporous and promote water and air exchange between the rooting substrate and surroundings. The containers may be biodegradable or compostable depending on the material and the manufacturing process. Some containers include a natural or synthetic binding material such as resins, glue, wax, latex, or cow manure. Other containers depend on the material itself to provide structural stability and extended life span for long-term use. Pressed fiber containers tend to have varying degrees of rigidity, material strength, and decay resistance depending on source material and processing. Unlike plastic, which provides relatively consistent performance in a mechanized production system, the resiliency of pressed fiber containers depends on the container (source material, material moisture content, binder, etc.). Production practices affect the environment to which the containers are subjected (irrigation, use of shade/ supplemental lighting, ambient temperature, etc.). Plant rooting pattern, pot spacing, and production duration can also influence container performance and lifespan. Also, some types of fiber containers weigh significantly more than a thin-walled plastic container-especially when saturated with water, which impacts container movement during production as well as shipping costs.

Bioplastics. Bioplastics are similar to traditional plastics and are created from either biopolymers (nonpetroleum based) or a blend of biopolymers and petrochemicalbased polymers. Biopolymer-based plastics are produced using renewable raw materials. Starch or cellulose is obtained from organic feed stocks [i.e., beet (Beta vulgaris), corn (Zea mays), potato (Solanum tuberosum), cassava (Manihot esculenta), sugarcane (Saccharum officinarum), palm fiber, or wheat]. Protein is acquired from soybeans (Glycine max) or keratin from waste poultry feathers. Lipids are derived from plant oils and animal fats. These raw materials are usually blended with fossil fuelbased polymers derived from petrochemical refining to reduce cost, enhance performance, or both (Riggi et al., 2011). There are two main types of bioplastics currently used in the manufacture of nursery containers: 1) starch-based plastics and 2) poly lactic acid (PLA). Starchbased plastics are water soluble, so starch blends are produced by linking $20 \%$ to $80 \%$ of starch with either biobased or fossil fuel-based polymers to improve their physical and chemical characteristics. Poly lactic acid is produced by anaerobic fermentation of feedstock and is mainly used with starch blends due to their slow biodegradability in soil. Bioplastics can be processed on equipment designed for petrochemical plastics, eliminating the need to develop new industrial machinery (Koeser et al., 2013a). The advantages of bioplastics are their physical properties including light weight, structural stability, rigidity, resistance to decay, and being the most similar to traditional plastics, which allows them to be easily integrated into a wide variety of production systems involving both shortterm and long-term crops. Most bioplastic containers are intended to be removed and either composted or anaerobically digested at the end of plant production. The slow degradability inherent to bioplastics would affect root establishment if the container was not removed before transplanting. Some containers such as the SoilWrap (Ball Horticultural Co., West Chicago, IL), a bioplasticbased sleeve design (see below), will degrade in the soil and are considered plantable pots.

SLEeves. There are several types of containers available in small sizes that are simply growing substrate wrapped in a paper, fiber, or bioplastic sleeve. These are not true containers, as they must be kept in a tray until the plant's roots hold the substrate together. These are often paper containers, which are plantable and fully degrade in a single season in the central and southern United States. Further north, they may persist for over 1 year. An example of commercially available sleeve is Ellepot (Blackmore Co., Belleville, MI) made from paper.

\section{Effect of alternative containers on plant production}

While biocontainers can reduce waste going into the landfill, that is only one of many environmental and economic aspects that may change as a grower transitions from conventional plastic pots to alternative containers. Past and ongoing research has documented differences and similarities regarding plant growth, plant quality, water requirements, mechanized production success, transplant shock, and a variety of containerrelated physical attributes. This section summarizes the current knowledge and potential issues associated with production and postproduction biocontainer use.

Plant growth AND QUality. Positive and negative impacts of using biocontainers compared with plastic containers have been reported on plant growth and development during production or establishment into the landscape. At the Center for Applied Horticulture Research (CAHR, Vista, CA), tomato (Solanum lycopersicum) plants grown in plastic containers had greater shoot dry weight than plants grown in wood fiber (Fertil Pot/DOT Pot; Fertil International, Boulogne-Billancourt, France), decomposed cow manure (CowPot; East Canaan, CT), and coconut coir pots but not different from 
plants grown in recycled paper (Western Pulp; Corvallis, OR) containers (CAHR, 2009). Root dry weight was greater for plants in plastic containers compared with all other container types. When planted in the field, recycled paper and coir containers degraded more slowly than Fertil Pot/DOTPot and CowPot. 'Midnight' (Dreams) petunia (Petunia $\times$ bybrida) grown in bioplastic (SoilWrap) and slotted rice hull (NetPot; Summit Plastic Co., Akron, $\mathrm{OH}$ ) containers had a larger growth index compared with plants grown in plastic pots; whereas, plants grown in bioplastic (Terra Shell/OP47, Summit Plastic Co.), coir, and plastic pots were not different (CAHR, 2010). Petunia flower number was not different during production or postproduction for plants grown in bioplastic (SoilWrap), rice hull (NetPots), and coir containers compared with plants in plastic control containers (CAHR, 2010). Similarly, recycled paper, peat (Jiffy-Pot; Jiffy International, Kristiansand, Norway), bioplastic (Terra Shell/OP47), rice straw, cow manure, coconut coir, and rice hull container types produced marketable transplants ['Score Red' geranium (Pelargonium $\times$ hortorum), 'Dazzler Lilac Splash' impatiens (Impatiens wallerana), and 'Grape Cooler' vinca (Catharanthus roseus)] within the same time frame (Kuehny et al., 2011). Kuehny et al. (2011) also investigated shoot dry weight of 'Dazzler Lilac Splash' impatiens produced in 4- and 5-inch biocontainers at three sites. For the 5-inch size containers, there was no difference in shoot dry weight at any location. For the 4-inch size, no container type was superior for all measurements (root and shoot dry weight and root: shoot ratio) at all three locations. Following greenhouse production, plants in plantable containers were installed in the Longwood Gardens (Kennett Square, PA) landscape and generally performed no differently than plants produced in plastic containers (Kuehny et al., 2011).

'Eckespoint Classic Red' poinsettia (Euphorbia pulcherrima) plants grown for 12 to 16 weeks in recycled paper (Western Pulp) containers under greenhouse conditions were reported to have increased root and shoot dry weight, plant height, and bract area index compared with plants grown in straw (StrawPot; Ivy Acres, Baiting Hollow, NY), composted cow manure (CowPot), coconut coir, rice hull (NetPot), wheat starchderived bioresin (Terra Shell/OP47), plastic, and sphagnum peatmoss and wood pulp (Jiffy-Pot) containers (Lopez and Camberato, 2011). In an experiment using ebb-and-flood irrigation, shoot dry weight of 'Rainier Purple' cyclamen (Cyclamen persicum) grown in bioplastic, solid rice hull, slotted rice hull, recycled paper, peat, cow manure, rice straw, and coconut coir containers for 15 weeks was greater than for plants grown in plastic containers (Beeks and Evans, 2013a). A 3-month study showed no negative impact of plantable containers [bioplastic (SoilWrap), paper (Ellepot) and slotted rice hull] on root and shoot development of two sedum species (Sedum bybridum 'Immergrunchen' and Sedum spuricum 'Red Carpet Stonecrop') and 'Big Blue' liriope (Liriope muscari) during production in a quonset and in the landscape (Ingram and Nambuthiri, 2012).

Water use. Evans and Hensley (2004) found that peat containers wicked water from the substrate causing 'Janie Bright Yellow' marigold (Tagetes patula), 'Cooler Blush' vinca, and 'Orbit Cardinal' geranium plants to wilt. Plants grown in peat (Jiffy-Pot) containers had the lowest shoot dry weight of all three container types, whereas plants had the greatest shoot dry weight when grown in plastic containers followed by plants grown in poultry feather containers. Tomato seedlings grown in corn/ palm-derived biocontainers had reduced biomass compared with those in plastic containers (Sakurai et al., 2005a). Further, seedlings in biocontainers had slower initial establishment in the field compared with those grown in plastic containers (Sakurai et al., 2005b). The researchers attributed this to inadequate irrigation and temporary root restriction of plants grown in biocontainers (Sakurai et al., 2005a, 2005b). Plant biomass is sometimes greater when plants are produced in alternative containers, but in other research, plants produced in conventional plastic containers have greater growth. The inconsistency may be due to increased potential for water loss through biocontainer sidewalls and related factors, which are the subject of this section.

Some disparity in alternative container research results may be due to irrigation frequency, individual crop species water use, evaporative demand in the experiment location, plant size, and differences in container size and dimension. Because of the semiporous nature of some alternative materials, there is an increased potential for water loss through biocontainer sidewalls during plant production, wicking moisture from the substrate and increasing the crop water requirement. Also, the combination of stage of production and evaporation through biocontainer sidewalls may influence water loss. For example, as plants grew larger, a once per day irrigation regime was no longer sufficient for crops grown in coconut coir containers but was sufficient for other alternative containers and conventional plastic containers during experiments conducted at CAHR (L. Villavicienco, personal communication).

The average water use of Gold Splash wintercreeper (Euonymus fortunei) plants grown outdoors in l-gal paper and recycled paper containers was $30 \%$ to $50 \%$ higher than those grown in standard plastic containers in a 4-month study in Texas (unpublished data). In a separate study, the highest rate of sidewall water loss was for wood fiber (Fertil), followed by peat (Jiffy-Pot), and composted manure (CowPot) and lower sidewall water loss was noticed with coir, rice straw, and slotted rice hull (unpublished data). The lowest sidewall evaporation was observed for bioplastic (Terra Shell/OP47), solid rice hull, and traditional plastic containers. Total loss of water after $8 \mathrm{~h}$ in an environment-controlled chamber under a vapor pressure deficit of $2.6 \mathrm{kPa}$ was $\approx 15 \%$ for plastic- and rice-hullbased containers, whereas the loss was $\approx 50 \%$ for recycled paper containers (Nambuthiri et al., 2012).

Porous containers (wood fiber, manure, and straw) required more water and produced smaller 'Yellow Madness' petunia plants compared with plants grown in plastic containers in a greenhouse study (Koeser et al., 2013b). The amount of water required for producing a 4 -inch 'Score Red' geranium, ranged from $0.55 \mathrm{gal} /$ container [plastic, rice hull, 
and bioplastic (Terra Shell/OP47] to $1.1 \mathrm{gal} /$ container [wood fiber, peat (Jiffy-Pot), rice straw, and recycled paper (Western Pulp)] under greenhouse and retail environments, necessitating an increased irrigation frequency for plants grown in biocontainers (Taylor et al., 2011). In a greenhouse study, 'Cooler Blush' vinca and 'Dazzler Rose Star' impatiens grown in peat-based containers required three times more water than plants grown in plastic containers (Evans and Karcher, 2004). Similarly, plants grown in feather-based containers required 2.5 times more water than those grown in plastic containers. The greater irrigation requirement was due to evaporation through sidewalls of peat and feather containers compared with impermeable plastic. The greater drying rate of biocontainers means increased irrigation volume, more frequent irrigation, or both, which could adversely affect the economic and environmental sustainability of alternative containers. Ebb-and-flood irrigation was found to be a viable option for conserving water when using biocontainers (bioplastic, solid rice hull, slotted rice hull, recycled paper, and coconut coir) in greenhouse production (Beeks and Evans, 2013b). Reusable plastic shuttle trays to support biocontainers may further reduce irrigation requirements (Koeser et al., $2013 b$ ). Irrigation is an important aspect of container plant production. Refining irrigation practices to match water loss and identifying waterconserving strategies such as use of shuttle trays will be critical to successfully adopting biocontainers in nursery and greenhouse production. Additionally, research is needed to examine how potentially greater or more frequent irrigation influences weed pressure, and herbicide and fertilizer longevity.

Substrate temperature. The importance of keeping substrate temperature below $100^{\circ} \mathrm{F}$ to avoid root injury is well documented (Kramer, 1949). However, during warmer months supraoptimal substrate temperatures can occur due to large solar influx and lack of heat dissipation from the nonporous black plastic containers (Beattie et al., 1987). In the southeastern United States, it is common for the substrate temperature in black plastic containers to exceed $107.5{ }^{\circ} \mathrm{F}$ for several hours and injure roots (Ruter and Ingram, 1990). Using porous containers (clay, paper, peat, etc.) is one method of mitigating heat stress as the root zone experiences a slower increase in temperature than when in nonporous containers (plastic, glass, paraffin protected, etc.) due to the high latent heat of vaporization of water (Jones, 1931).

Maximum root-zone temperature of wood fiber containers was $\approx 8{ }^{\circ} \mathrm{F}$ lower than that of black plastic containers in a southern Georgia study (Ruter, 2000b) as the fiber containers are semiporous and promote water and air exchange between the rooting substrate and surroundings. Shrub rose (Rosa sp.) grown in Texas in black plastic pots experienced substrate temperature of about $130.8^{\circ} \mathrm{F}$ compared with only $97.4^{\circ} \mathrm{F}$ of those grown in fabric (Smart Pots) containers (Arnold and McDonald, 2006). Fiber containers were found to improve plant production, survival, and quality by moderating the substrate temperature of 'Otto Luyken' cherry laurel [Prunus laurocerasus (Ruter, 1999)] and Gold Splash wintercreeper (Fulcher et al., 2012; Wang et al., 2012) compared with plastic containers. 'Cunningham's White' rhododendron (Rhododendron $x$ ) grown in fiber containers were never exposed to temperatures greater than $104{ }^{\circ} \mathrm{F}$, whereas the plants grown in plastic containers experienced supraoptimal temperatures $\left(>122{ }^{\circ} \mathrm{F}\right)$ especially when located on the southwest part of the production area (Svenson, 2002). 'Aztec Gold' daylily (Hemerocallis) grown in fiber containers produced three times greater foliage dry weight and four times greater root dry weight than those grown in plastic containers, which was attributed to lower substrate temperature and improved aeration for the plants grown in fiber containers (Ruter, 2000a). In a laboratory study, greater substrate temperatures were observed in plastic, bioplastic (Terra Shell/OP47) and rice hull containers compared with lower heat buildup in decomposed cow manure (CowPot), wood fiber pot (Fertil), coir, peat (Jiffy-Pot), rice straw, and slotted rice hull containers due to the increased evaporative cooling and the fact that fiber containers reflect more light compared with standard plastic containers (Nambuthiri et al., 2012). Use of fiber containers may be a management tool for growing plants that are particularly temperature-sensitive.

Container NUTRIENT SOURCE. The aforementioned lack of consistency in growth may be partly due to the capacity of containers from different materials to affect the plant nutrient status by supplying different levels of nitrogen during production. For example, Schrader et al. (2013b) found that containers composed exclusively of soybean-based bioplastic containers supplied excess nitrogen, whereas those composed of a blend of PLA and soy-based plastic added nitrogen at a desirable rate. Additionally, Schrader et al. (2013b) found that removing, crushing, and placing the container in the ground near the root zone at transplant increased fruit production as well as shoot dry weight, shoot volume, and plant quality index compared with polypropylene plastic. More research is needed to determine the influence of parent container material on plant growth, plant nutrient status, and fertilization requirements during and postproduction.

Container integrity AND APPEARANCE. Alternative containers vary in both integrity and strength during production and marketing. Greenhouse managers have reported loss of saleable products and potential injury liability as some biocontainers are easily broken during shipping or by mechanized systems. The physical strength of peat and cow manure containers indicates that some biocontainers may tear or break during greenhouse production, packaging, shipping, and retailing especially when wet (Koeser et al., 2013a), necessitating more careful handling until they are installed in the landscape.

Evans et al. (2010) found rice hull, coir, and recycled paper containers have the greatest wet and dry vertical and lateral strength among biocontainers tested, similar to those of plastic containers and had no algal or fungal growth on container walls. Porous rice straw containers and bioplastic (Terra Shell/OP47) with a thin wall had the lowest dry punch strengths. Containers composed of fiber, composted manure (CowPot), or peat (Jiffy-Pot) had low wet vertical 
strength and intermediate dry vertical strength. Poor wet strength was reported for wood fiber (Fertil), peat (Jiffy-Pot) and composted manure pot (CowPot). Containers with sidewalls that absorb moisture can soften and develop algal and fungal growth and a subsequent reduction in strength (Evans and Karcher, 2004). In a 14-week greenhouse evaluation of 'Eckespoint Classic Red' poinsettia production, color and integrity of plastic, rice hull, wheat starch (TerraShell/OP47), and recycled paper (Western Pulp) containers remained unchanged, whereas plants with acceptable quality grown in peat (Jiffy-Pot) and composted cow manure (CowPot) containers were not marketable due to loss of container integrity or mold and/or algal growth creating a poor appearance (Lopez and Camberato, 2011). Bioplastic, solid rice hull, and slotted rice hull containers were good plastic alternatives in a 15-week greenhouse study with 'Rainer Purple' cyclamen (Beeks and Evans, 2013b). During this research, these containers had similar irrigation requirements, retained high levels of punch and tensile strength, and supported no microorganism growth. However, peat, cow manure, wood fiber, and rice straw containers were not acceptable replacements for plastic containers due to substantial microorganism growth on the containers, weak strengths of containers at the end of the production period, and more frequent irrigation requirements when compared with plastic containers (Beeks and Evans, 2013b). Growers and consumers have to consider that the same physical characteristics that promote degradation in the landscape or during composting could also contribute to premature degradation during production, transportation, and/or point of purchase, hampering efficient handling during production and retail sales. Some alternative container types may be more suited to long-term production crops, while others may be better suited to shortterm greenhouse production.

BIODEGRADABILITY POST TRANSPLANTING. Biodegradability of containers in soil depends on soil organic matter content, rooting pattern of crop, weather, cultural practices, and carbon-nitrogen ratio of containers (unpublished data). Plantable containers reduce waste and increase labor efficiency during installation. As previously mentioned, degradation before planting can be detrimental, yet porosity and the ability to degrade in soil are essential characteristics that support use of alternative containers in landscapes.

In a landscape trial conducted at multiple locations, none of the five plantable biocontainer types used were completely degraded 8 weeks after planting; composted manure (CowPot), which has high cellulose and nitrogen content, had the greatest container decomposition, whereas peat (Jiffy-Pot) and rice straw containers showed moderate degradation, and coir containers had the lowest level of decomposition likely due to its high lignin content (Evans et al., 2010). Similarly, a field study using tomato transplants (Vista, CA vicinity) found faster degradation of composted cow manure (CowPot) and wood fiber plus peat (Fertil Pot/ DOTPots) compared with recycled paper and coir containers (CAHR, 2009). For landscape beds replanted each season, these data suggest that certain types of containers would need to be removed or manually broken apart and incorporated into the soil before the bed can be replanted. Slow container degradation posttransplanting could cause root circling, leading to restricted water and nutrient movement and ability to adequately anchor (Appleton, 1993). More research is required to develop standards for "biodegradability" of alternative containers.

Lifespan. Container life span can vary from a few months to several years to match the crop production cycle. One economic consideration with many alternative containers is the inability to reuse them, either because they are designed to be planted with the crop or because they will degrade substantially during one production cycle. This may increase production costs for some growers. Studies are ongoing to extend the lifespan of biocontainers using various natural or synthetic adhesives, resins, waxes, and binding agents that determine the rate of containers biodegradability or compostability (Schrader et al., 2013a). In general, biocontainers designed for shortterm crops such as vegetables, herbs, and seasonal flowering plants must last a few months, whereas nursery containers must last from one to three years and usually are not quickly biodegradable, but may be compostable.

\section{Marketing}

Biocontainers can be considerably more expensive, typically $10 \%$ to $40 \%$ more than their plastic counterparts (Robinson, 2008). This increased cost means that growers must be able to realize a premium price for plants grown in biocontainers or reduce production costs for the system to be economically viable. Hall et al. (2010) reported an increased customer demand for biodegradable containers compared with the traditional plastic container. Another study determined the willingness of consumers to pay more for biodegradable containers using experimental auctions in which consumers made purchases (Yue et al., 2010a). This system allowed researchers to determine what consumers will actually do compared with what they say they will do on a survey. The results revealed that consumers are willing to pay $\$ 0.58$ more for a chrysanthemum (Dendranthema $\times$ morifolium) in a 4 -inch rice hull container, $\$ 0.37$ more for a straw container, and $\$ 0.23$ more for a bioplastic container than for a chrysanthemum in a traditional black plastic container. During the 2010 National Poinsettia Cultivar Trials at Purdue University (West Lafayette, IN), consumers were willing to pay $\$ 0.50$ or $\$ 1$ more for 'Eckespoint Classic Red' poinsettias grown in hard rice hull, Terra Shell/OP47, recycled paper, and coir fiber containers than those grown in plastic containers (Camberato and Lopez, 2010). Environmentally friendly packaging was found to increase the likelihood of purchasing fresh-cut flowers and floral products (Rihn et al., 2011). These studies reflect a potential area for improving marketing and sales of nursery and floriculture products.

\section{Future prospects}

The limited supply of petrochemicals for conventional plastic containers and the increasing worldwide demand for petroleum will continue to dictate greenhouse and nursery container prices (U.S. Energy 
Information Administration, 2013). Additionally, consumers are becoming increasingly aware of and interested in the green industry's impact on the environment. Therefore, economic and social pressure to reduce plastic use and increase sustainable production practices will only increase. The green industry must consider greater reuse and recycling of plastic products as well as containers made of alternative materials to satisfy the demands of their businesses and customers. Growers and landscapers must evaluate the compatibility of the entire production system from planting and irrigation, to harvesting, transportation and marketing, as well as, crop species, business location, level of mechanization, and many other factors to successfully integrate a new container type (Dennis et al., 2010). Identification of container types suited to crop cycles of varying duration (i.e., short-term, long-term) is needed.

The economic and environmental viability of alternative containers including the carbon and water footprints associated with manufacture, transport, and use of these new products is not yet fully understood. The environmental benefits of using alternative containers must be weighed against potential challenges and associated losses incurred due to the decrease in container integrity over time as well as other increased costs (e.g., increased water usage and energy requirements of industrial composting). Recently, alternative containers impregnated with various components such as natural color, slow release fertilizers, fungicides, insecticides, and plant growth regulators that are released during plant growth are gaining entry to the market and could enhance production system efficiency. Members of the green industry, allied industries, and researchers must continue to work together to develop and fine-tune sustainable alternative containers that are compatible with current production practices and are economically feasible.

\section{Literature cited}

Amidon Recycling. 1994. Use and disposal of plastics in agriculture. A report prepared for the American Plastics Council. Amidon Recycling, Wilton, NH.
Appleton, B.L. 1993. Nursery production alternatives for reduction or elimination of circling tree roots. J. Arboricult. 19:383-388.

Arnold, A.M. and G.V. McDonald. 2006. Shrub rose responses to production in smart pots and conventional containers using two contrasting substrates. Subtrop. Plant Sci. J. 58:1-4.

ASTM. 2004. Standard D6400-04 standard specification for compostable plastics. ASTM, West Conshohocken, PA.

Beattie, D.J., R. Berghage, V. Puri, and E. Biddinger. 1987. Plant growth thrives on a high fiber diet: The pros and cons of fiber containers for nursery growing. Nursery Mgt. Production 15:81-83.

Beeks, S.A. and M.R. Evans. 2013a. Growth of cyclamen in biocontainers on an ebb-and-flood subirrigation system. HortTechnology 23:173-176.

Beeks, S.A. and M.R. Evans. 2013b. Physical properties of biocontainers used to grow long-term greenhouse crops in an ebb-and-flood irrigation system. HortScience 48:732-737.

Behe, B.K., B.L. Campbell, C.R. Hall, H. Khachatryan, D.H. Dennis, and C.Y. Yue. 2013. Consumer preferences for local and sustainable plant production characteristics. HortScience 48:200-208.

Camberato, D.M. and R.G. Lopez. 2010. Biocontainers for long-term crops. Greenhouse Grower 28:27-28.

Center for Applied Horticulture Research. 2009. Effect of biocontainer type on shoot and root growth of tomatoes and coir pot effect on field establishment on tomato plants. 31 Dec. 2013 $<$ http://www.cfahr.org/center/Annual Report.html>.

Center for Applied Horticulture Research. 2010. Performance of biopots under greenhouse conditions. 31 Dec. 2013 . <http://www.cfahr.org/ 2010AnnualReport/Part9.pdf>.

Dennis, J.L., R.G. Lopez, B.K. Behe, C.R. Hall, C. Yue, and B.L. Campbell. 2010. Sustainable production practices adopted by greenhouse and nursery plant growers. HortScience 45:1232-1237.

Evans, M.R. and D.L. Hensley. 2004. Plant growth in plastic, peat, and processed poultry feather containers. HortScience 39:1012-1014.

Evans, M.R. and D. Karcher. 2004. Properties of plastic, peat and processed poultry feather growing containers. HortScience 39:1008-1011.

Evans, M.R., M. Taylor, and J. Kuehny. 2010. Physical properties of biocontainers for greenhouse crops production. HortTechnology 20:549-555.

Fulcher, A., G. Niu, G. Bi, M.R. Evans, T. Fernandez, R. Geneve, A. Koeser, S. Nambuthiri, N. Pershey, R. Stewart, S. Verlinden, and X. Wang. 2012. Assessing biocontainers and a sustainable irrigation regime for the US nursery industry. Proc. Southern Nursery Assn. Res. Conf. 57:73-77.

Garthe, J.W. and P.D. Kowal. 1993. Recycling used agricultural plastics. Penn State Fact Sheet C-8. 15 Oct. 2013. $<$ http://pubs.cas.psu.edu/freepubs/ pdfs/C8.pdfs.

Hall, C.R., B.L. Campbell, B.K. Behe, C. Yue, R.G. Lopez, and J.H. Dennis. 2010. The appeal of biodegradable packaging to floral consumers. HortScience 45:583-591.

Hall, T.J., J.H. Dennis, R.G. Lopez, and M.I. Marshall. 2009. Factors affecting growers' willingness to adopt sustainable floriculture practices. HortScience 44:1346-1351.

Helgeson, M.S., W.R. Graves, D. Grewell, and G. Srinivasan. 2009. Degradation and nitrogen release of zein-based bioplastic containers. J. Environ. Hort. 27:123127.

Ingram, D.L. and S. Nambuthiri. 2012. Using plantable containers for selected groundcover plant production. HortScience 47:S26.(abstr.).

Jones, L.H. 1931. Effect of the structure and moisture of plant containers on the temperature of the soil contents. J. Agr. Res. 42:375-378.

Khan, A.A., T. Mahmood, and B. Bano. 2000. Development of bio-decomposable (Jiffy) pots for raising and transplanting nursery plants. Intl. J. Agr. Biol. 2:380381 .

Knox, G.W. and M. Chappell. 2011. Alternatives to petroleum-based containers for the nursery industry. Florida Coop. Ext. Serv. ENH1193.

Koeser, A.K., G. Kling, C. Miller, and D. Warnock. 2013a. Compatibility of biocontainers in commercial greenhouse crop production. HortTechnology 23:149-156

Koeser, A.K., S.T. Lovell, M.R. Evans, and J.R. Stewart. 2013b. Biocontainer water use in short-term greenhouse crop production. HortTechnology 23:215-219.

Kramer, P.J. 1949. Plant and soil water relationships. McGraw Hill, New York.

Kuehny, J.S., M. Taylor, and M.R. Evans. 2011. Greenhouse and landscape performance of bedding plants in biocontainers. HortTechnology 21:155-161. 
Lopez, R.G. and D. Camberato. 2011. Growth and development of 'Eckespoint Classic Red' poinsettia in biodegradable and compostable containers. HortTechnology 21:419-423.

Nambuthiri, S., R. Geneve, T. Fernandez, A. Fulcher, A. Koeser, G. Bi, M.R. Evans, G. Niu, N. Pershey, R. Stewart, S. Verlinden, and X. Wang. 2012. Substrate heat buildup and evaporation rate differs between plastic and alternative one gallon nursery containers. Proc. Southern Nursery Assn. Res. Conf. 57:60-62.

Riggi, E., G. Santagata, and M. Malinconico. 2011 . Biobased and biodegradable plastics for use in crop production. Recent Patents Food Nutr. Agr. 3:49-63.

Rihn, A.L., C. Yue, B. Behe, and C. Hall. 2011. Generations X and Y attitudes toward fresh flowers as gifts: Implications for the floral industry. HortScience 46:736-743.

Robinson, T. 2008. Containers evolve to satisfy industry, retailer, and consumer needs. GMPro 28:35-40.

Ruter, J.M. 1999. Fiber pots improve survival of 'Otto Luyken' laurel. Proc. Southern Nursery Assn. Res. Conf. $44: 37-38$.

Ruter, J.M. 2000a. Biodegradable fiber containers improve the growth of two daylily cultivars. Acta Hort. 517:271273.

Ruter, J.M. 2000b. Cross-country containers. Amer. Nurseryman 191:26-31.
Ruter, J.M. and D.L. Ingram. 1990.

${ }^{14}$ Carbon-labeled photosynthate partitioning in Ilex crenata 'Rotundifolia' at supraoptimal root-zone temperatures. J. Amer. Soc. Hort. Sci. 115:1008-1013.

Sakurai, K., A. Ogawa, C. Kawashima, and M. Chino. 2005a. Effects of biodegradable seedling containers on growth and nutrient concentrations of tomato plants: 1. Growth and nutrient concentrations before planting. Hort. Res. 4:271-274.

Sakurai, K., A. Ogawa, C. Kawashima, and M. Chino. 2005b. Effects of biodegradable seedling containers on growth and nutrient concentrations of tomato plants: 2. Growth and nutrient concentrations after transplanting. Hort. Res. 4:275-279.

Schrader, J. 2013. Report on the annual consumption of plastics for specialty-crop containers in the United States. 7 Jan. 2014. <http://www.public.iastate.edu/ $\sim$ bioplastic/Images\%20Folder/Contain er\%20plastics\%20estimate.pdf>.

Schrader, J., K. McCabe, G. Srinivasan, D. Grewell, S. Madbouly, M. Kessler, and W. Graves. 2013a. Evaluation of bioplasticcoated fiber containers for greenhouse grown plants. HortScience 48:S255-S256 (Abstr.).

Schrader, J.A., G. Srinivasan, D. Grewell, K.G. McGabe, and W.R. Graves. 2013b. Fertilizer effects of soy-plastic containers during crop production and transplant establishment. HortScience 48:724-731.
Svenson, E.S. 2002. Growth of 'Cunningham's White' rhododendron in plastic and fiber pots treated with copper hydroxide. HortTechnology 12:134-137.

Taylor, M., M. Evans, and J. Kuehny. 2011. Biocontainers - Water requirements. Greenhouse Mgt Production 31:32-34.

U.S. Energy Information Administration. 2013. International energy outlook 2013. DOE/EIA-0484. U.S. Department of Energy, Washington, DC.

Wang, X., T. Fernandez, B. Cregg, A. Fulcher, R. Geneve, G. Niu, S. Verlinden, M. Ngouajio, T. Kijchavengku, R. Auras, G. Bi, S. Nambuthiri, and R. Conneway. 2012. Performance of alternative containers and plant growth and water use of Euonymus fortunei. HortScience 47:S87. (abstr.).

Yue, C., C.R. Hall, B.K. Behe, B.L. Campbell, J.H. Dennis, and R.G. Lopez. 2010a. Are consumers willing to pay more for biodegradable containers than for plastic ones? Evidence for hypothetical conjoint analysis and nonhypothetical experimental auctions. J. Agr. Appl. Econ. 42:757-772.

Yue, C., J.H. Dennis, B.K. Behe, C.R. Hall, B.L. Campbell, and R.G. Lopez. 2011. Investigating consumer preferences for organic, local, or sustainable plants. HortScience 46:610-615. 